\title{
Early epidemiological indicators, outcomes, and interventions of COVID-19 pandemic: A systematic review
}

\author{
Urvish Patel ${ }^{1}$, Preeti \\ Malik ${ }^{1}$, Deep Mehta ${ }^{2}$, \\ Dhaivat Shah², Raveena \\ Kelkar², Candida Pinto', \\ Maria Suprun ${ }^{3}$, Mandip \\ Dhamoon ${ }^{4}$, Nils Hennig 5 , \\ Henry Sacks ${ }^{6}$
${ }^{1}$ Department of Public Health, Icahn School of Medicine at Mount Sinai, New York, USA
${ }^{2}$ Clinical Research Program, Icahn School of Medicine at Mount Sinai, New York, USA
${ }^{3}$ Department of Pediatrics, Allergy, and Immunology, Icahn School of Medicine at Mount Sinai, New York, USA
${ }^{4}$ Department of Neurology, Icahn School of Medicine at Mount Sinai, New York, USA
${ }^{5}$ Department of Environmental Medicine and Public Health, Pediatric Infectious Diseases, Health System Design and Global Health, Icahn School of Medicine at Mount Sinai, New York, USA
${ }^{6}$ Department of Environmental Medicine and Public Health, Icahn School of Medicine at Mount Sinai, New York, USA

\section{Correspondence to:}

Preeti Malik, MD, MPH

Department of Public Health

Icahn School of Medicine at Mount Sinai

1 Gustave L. Levy Pl

New York, NY 10029

USA

pmalik.ma@gmail.com

\begin{abstract}
Background Coronavirus disease-2019 (COVID-19), a pandemic that brought the whole world to a standstill, has led to financial and health care burden. We aimed to evaluate epidemiological characteristics, needs of resources, outcomes, and global burden of the disease.

Methods Systematic review was performed searching PubMed from December 1, 2019, to March 25, 2020, for full-text observational studies that described epidemiological characteristics, following MOOSE protocol. Global data were collected from the JHU-Corona Virus Resource Center, WHO-COVID-2019 situation reports, KFF.org, and Worldometers.info until March 31, 2020. The prevalence percentages were calculated. The global data were plotted in excel to calculate case fatality rate (CFR), predicted CFR, COVID-19 specific mortality rate, and doubling time for cases and deaths. CFR was predicted using Pearson correlation, regression models, and coefficient of determination.
\end{abstract}

Results From 21 studies of 2747 patients, 8.4\% of patients died, 20.4\% recovered, $15.4 \%$ were admitted to ICU and $14.9 \%$ required ventilation. COVID-19 was more prevalent in patients with hypertension (19.3\%), smoking (11.3\%), diabetes mellitus (10\%), and cardiovascular diseases (7.4\%). Common complications were pneumonia (82\%), cardiac complications $(26.4 \%)$, acute respiratory distress syndrome (15.7\%), secondary infection (11.2\%), and septic shock (4.3\%). Though CFR and COVID-19 specific death rates are dynamic, they were consistently high for Italy, Spain, and Iran. Polynomial growth models were best fit for all countries for predicting CFR. Though many interventions have been implemented, stern measures like nationwide lockdown and school closure occurred after very high infection rates (>10cases per 100000 population) prevailed. Given the trend of government measures and decline of new cases in China and South Korea, most countries will reach the peak between April 1-20, if interventions are followed.

Conclusions A collective approach undertaken by a responsible government, wise strategy implementation and a receptive population may help contain the spread of COVID-19 outbreak. Close monitoring of predictive models of such indicators in the highly affected countries would help to evaluate the potential fatality if the second wave of pandemic occurs. The future studies should be focused on identifying accurate indicators to mitigate the effect of underestimation or overestimation of COVID-19 burden.

Since its inception in Wuhan, China in December 2019, coronavirus disease 2019 (COVID-19) has spread throughout the world and has been declared a pandemic by World Health Organization (WHO) on March 11, 2020 [1]. As of April 12020, 
there are 935197 confirmed cases worldwide with 47192 (5.04\%) deaths and 193989 (20.7\%) recovered cases [2]. New York is the current epicenter of COVID-19 (102863 cases and 2935 deaths) of United States of America (USA) (215003 cases, 5102 (2.37\%) deaths and 8878 (4.13\%) recovered patients) while Italy (13 155 deaths) and Spain (10003 deaths) being worst affected countries [2,3]. Globally, the epidemiological scenario of COVID-19 is changing on a daily basis.

The origin of severe acute respiratory syndrome coronavirus (SARS-CoV-2) virus was linked to a seafood market in Wuhan from the handling and close contact with animals [4]. In USA, the first case was reported on January 20, 2020, with a recent travel history to Wuhan [5]. According to emerging literature, COVID-19 symptoms can range from mild respiratory illness causing fever, dry cough, dyspnea, myalgia and fatigue to more severe manifestation of pneumonia, cardiac complications requiring intensive care unit (ICU) admission and mechanical ventilation [6]. The median incubation period is around 5 days (range:2-14 days), requiring prolonged monitoring in extreme cases [7,8]. Real-time reverse transcriptase polymerase chain reaction (RT-PCR) of nasopharyngeal and/or oropharyngeal swabs are usually used to confirm the diagnosis $[9,10]$. Preliminary demographic data of the infected patients suggests that most patients have mild disease, with older adults ( $\geq 65$ years) appearing to be more susceptible to severe illness requiring hospitalization $[11,12]$. COVID-19 shows evidence of human to human transmission via respiratory droplets and from contact with contaminated surfaces or objects, with estimated median basic reproduction number (RO) of 2.28 (range: 2.06-2.52) [13], making the spread of the disease tough to contain.

While recently published observational studies have provided insights on the epidemiology of this pandemic, their sample sizes are too limited for any definitive conclusions. Hence, we sought to conduct a systematic review and analysis of all available studies comparing outcomes. Primary aim of the study is to evaluate the epidemiological characteristics, needs of resources, and patients' outcomes. Secondary aim is to evaluate the global burden and interventions.

\section{METHODS}

\section{Primary aim evaluation}

\section{Endpoints}

We evaluated epidemiological characteristics, risk factors, laboratory and imaging findings, complications and treatment utilized. We also calculated the mortality, recovery, and needs of resources like ICU beds and mechanical ventilators.

\section{Eligibility criteria, search strategy and selection criteria}

In order to evaluate the primary outcome, we performed a systematic review of these observational studies according to MOOSE guidelines $[13,14]$. We searched the PubMed database for original observational studies that described any details on epidemiological characteristics on patients with COVID-19. The database was searched from December 1, 2019, to March 25, 2020. The search was conducted using the following keyword/MESH terms: ((COVID-19[Title/Abstract]) OR coronavirus [Title/Abstract]) OR SARS-CoV-2 [Title/Abstract] OR 2019-nCoV [Title/Abstract]. All studies that compared outcomes of interest in COVID-19 patients were included. Any literature other than observational studies was excluded. Non-English literature, non-full text, and animal studies were excluded. Abstracts were reviewed, and articles were retrieved accordingly. Two independent reviewers performed the search and literature screening (UP, PM), with disputes resolved by consensus following discussion with a third author (CP). For the ease of understanding, we used a flow diagram to describe literature search and study selection process in Figure S1 in the Online Supplementary Document.

\section{Data collection}

A prespecified data collection Excel sheet was used to collect the data relating to study characteristics and outcomes of interest by two authors (PM and CP), and discrepancies were solved by a discussion with a third author (UP). The following study characteristics were extracted: publication year, country of origin, sample size, age, sex, direct exposure to infection, travel history, signs and symptoms, risk factors and comorbidities, laboratory and radiology findings, treatment utilized, and complications. Data on the following outcomes were extracted: mortality, recovery, need for ICU beds and mechanical ventilators. 


\section{Statistical analysis}

All analysis was done in Excel (Microsoft Inc, Seattle WA, USA) and SAS 9.4 (SAS Institute, Cary, NC, USA). The frequencies and percentages of epidemiological characteristics and outcomes were calculated.

\section{Secondary aim evaluation}

We evaluated the global burden of COVID-19 including case fatality rates (CFR), strength of association between deaths and cases to predict CFR, case doubling time, COVID-19 specific mortality rates, and control measures by governments to prevent spread among USA, China, Italy, Iran, Spain, Germany, India, and South Korea. For this purpose, data were taken from the Johns Hopkins University Corona-Virus Resource Center [3], KFF.org [14], World Health Organization-COVID-2019 situation reports [15], and Worldometers.info [2] up until March 31, 2020. We evaluated changes in cases and deaths, CFR, created a predictive modeling for CFR, COVID-19 specific mortality rate, and doubling time for cases and deaths.

CFR was defined as the number of cases divided by the number of the diagnosed patients with COVID-19, and COVID-19 specific mortality rate was defined by deaths due to COVID-19 infections divided by total population of the country in 2020, counted per 100000 population [16] Pearson correlation coefficient ( $r$ ) was obtained to establish the strength of association between deaths and cases for individual countries. To predict CFR, we modelled the epidemic curves with simple linear regression, exponential growth, and polynomial growth models and used a coefficient of determination $\left(\mathrm{R}^{2}\right)$ for model selection. The time of reporting the first death was used as the starting point for that country for all three models.

We utilized government websites, national media, and other standard open sources to evaluate the governments' interventions during COVID-19 pandemic, infection rate [(diagnosed cases/country's population in 2020) per 100000 population] [16] at the time of interventions like nationwide school closure and lockdown, and effects of such measures to predict the dates of peak number of cases in each country.

\section{RESULTS}

\section{Primary outcomes}

Our search resulted in 1956 studies, out of which 1688 non-human studies and other than observational studies, 64 non-full text and articles with non-English language information were excluded. 224 full-text studies were screened and 45 studies with insufficient clinical information or outcomes-related information were excluded. 166 full-text articles were assessed for eligibility. The final analysis included 21 fulltext observational studies, presented in Table 1, including a total of 2747 patients.

Table 1. Studies used for this systematic review

\begin{tabular}{|c|c|c|c|c|c|}
\hline AUTHOR, MONTH, YEAR & DATA cOLLected In counthy & DATES OF COLLECTED DATA & CONFIRMED CASE & Discharge/Recovery & Deaths \\
\hline Lauer, Mar 2020 [17] & China & Jan 4, 2020 - Feb 24, 2020 & 181 & - & - \\
\hline Huang, Jan 2020 [18] & China & $\operatorname{Dec} 16,2019-\operatorname{Jan} 2,2020$ & 41 & 28 & 6 \\
\hline Guan, Feb 2020 [11] & China & Dec 11, 2019 - Jan 29, 2020 & 1099 & 64 & 15 \\
\hline Zhao, Mar 2020 [19] & China & Jan 23, 2020 - Feb 5, 2020 & 19 & 0 & 0 \\
\hline Young, Mar 2020 [20] & Singapore & Jan 23, $2020-$ Feb 3, 2020 & 18 & - & 0 \\
\hline Chang, Feb 2020 [21] & China & $\operatorname{Jan} 16,2020-\operatorname{Jan} 29,2020$ & 13 & 13 & 0 \\
\hline Wang, Feb 2020 [22] & China & Jan 1, 2020 - Jan 28, 2020 & 138 & 47 & 6 \\
\hline Ng, Mar 2020[23] & Singapore & Jan 2, 2020 - Feb 29, 2020 & 100 & - & 0 \\
\hline Spiteri, Mar 2020 [24] & Europe & Jan 24, 2020 - Feb 21, 2020 & 38 & - & 1 \\
\hline $\begin{array}{l}\text { COVID-19 National Incident Room } \\
\text { Surveillance Team, Mar } 2020 \text { [25] }\end{array}$ & Australia & 7 Mar 2020 & 71 & 22 & 2 \\
\hline $\mathrm{Xu}$, Feb 2020 [26] & China & Jan 10, $2020-\operatorname{Jan} 26,2020$ & 62 & - & 0 \\
\hline Bajema, Feb 2020 [27] & USA & Jan 20, 2020 & 11 & - & - \\
\hline Ki, Feb 2020 [28] & South Korea & Jan 20,2020 & 28 & - & - \\
\hline Chen, Jan 2020 [29] & China & Jan 1, 2020 - Jan 20, 2020 & 99 & 31 & 11 \\
\hline Zhang, Feb 2020 [30] & China & Jan 16, 2020 - Feb 3, 2020 & 140 & - & - \\
\hline Yang, Feb 2020 [31] & China & Dec 24, 2019 - Jan 26, 2020 & 52 & 8 & 32 \\
\hline Wang, Mar 2020 [32] & China & $\operatorname{Jan} 16,2020-\operatorname{Jan} 29,2020$ & 69 & 18 & 5 \\
\hline Mo, Mar 2020 [33] & China & Jan 1, $2020-$ Feb, 12020 & 155 & - & - \\
\hline Arentz, Mar 2020 [34] & USA & Feb 20, 2020 - Mar 5, 2020 & 21 & 2 & 11 \\
\hline Wu, Mar 2020 [35] & China & Dec 25, $2019-\operatorname{Jan} 26,2020$. & 201 & - & 44 \\
\hline Zhou, Mar 2020 [36] & China & Dec 29, 2019 - Jan 31, 2020 & 191 & 137 & 54 \\
\hline
\end{tabular}


Table 2. Epidemiological, clinical, laboratory characteristics and outcomes of the patients infected with COVID-19 analyzed in this review

\begin{tabular}{|c|c|}
\hline Total number of Confirmed Cases from Articles Reviewed & $N=2747$ \\
\hline Age (years) $($ Mean $\pm S D)$ & $48 \pm 10.3$ \\
\hline \multicolumn{2}{|l|}{ Gender: } \\
\hline Male & $1599 / 2736(58.4 \%)$ \\
\hline Female & $1130 / 2736(41.3 \%)$ \\
\hline Direct exposure with infected person & 909/1929 (47.1\%) \\
\hline Travel history to China & $371 / 1540(24.1 \%)$ \\
\hline China resident & $623 / 1420(43.8 \%)$ \\
\hline \multicolumn{2}{|l|}{ Symptoms: } \\
\hline Fever & $2209 / 2438(90.6 \%)$ \\
\hline Cough & $1656 / 2438(67.9 \%)$ \\
\hline Dyspnea & $554 / 2438(22.7 \%)$ \\
\hline Myalgia or fatigue & $1179 / 2438(48.3 \%)$ \\
\hline Sputum production/expectorant & $602 / 2438(24.7 \%)$ \\
\hline Headache & $235 / 2438(9.6 \%)$ \\
\hline Diarrhea & $121 / 2438(4.9 \%)$ \\
\hline Nausea/vomiting & $124 / 2438(5.1 \%)$ \\
\hline Hemoptysis & $14 / 2438(0.57 \%)$ \\
\hline Sore throat & $192 / 2438(7.9 \%)$ \\
\hline Nasal congestion & $25 / 2438(1 \%)$ \\
\hline \multicolumn{2}{|l|}{ Risk factors/comorbidities: } \\
\hline Hypertension & $422 / 2188(19.3 \%)$ \\
\hline Smoking & $189 / 1678(11.3 \%)$ \\
\hline Diabetes mellitus & $217 / 2169(10 \%)$ \\
\hline Cardiovascular disease & $166 / 2244(7.4 \%)$ \\
\hline Cerebrovascular disease & $32 / 960(3.3 \%)$ \\
\hline Pulmonary disease & $53 / 2169(2.4 \%)$ \\
\hline Chronic liver disease & $53 / 2188(2.4 \%)$ \\
\hline Malignancy & $39 / 2206(1.8 \%)$ \\
\hline Other comorbidities & $380 / 2157(17.6 \%)$ \\
\hline \multicolumn{2}{|l|}{ Laboratory parameters: } \\
\hline Leukopenia & $464 / 1668(27.8 \%)$ \\
\hline Lymphopenia & $634 / 1737(36.5 \%)$ \\
\hline Thrombocytopenia & $340 / 1389(24.5 \%)$ \\
\hline Elevated aspartate transaminase (AST) & $301 / 1527(19.7 \%)$ \\
\hline Elevated alanine transaminase (ALT) & $316 / 1678(18.8 \%)$ \\
\hline Elevated c-reactive protein (CRP) & 707/1388 (51\%) \\
\hline Elevated lactate dehydrogenase (LDH) & $700 / 1678(41.7 \%)$ \\
\hline Elevated creatinine kinase & $126 / 1408(9 \%)$ \\
\hline Elevated creatinine & $32 / 1590(2.01 \%)$ \\
\hline Elevated D-dimer & $457 / 1590(28.7 \%)$ \\
\hline Elevated total bilirubin & $104 / 1399(7.4 \%)$ \\
\hline $\begin{array}{l}\text { Elevated activated partial thromboplastin time } \\
\text { (APTT) }\end{array}$ & $25 / 292(8.6 \%)$ \\
\hline Elevated blood urea nitrogen (BUN) & $6 / 99(6 \%)$ \\
\hline Elevated erythrocyte sedimentation rate (ESR) & $55 / 224(24.5 \%)$ \\
\hline \multicolumn{2}{|l|}{ Computed tomography (CT) scan use: } \\
\hline Abnormal CT chest & $1321 / 1598(82.7 \%)$ \\
\hline Bilateral lung affected & $1445 / 2197(65.7 \%)$ \\
\hline Ground glass opacity & $975 / 1637(59.5 \%)$ \\
\hline \multicolumn{2}{|l|}{ Treatments utilized: } \\
\hline Antibiotic use & $1406 / 2042(68.8 \%)$ \\
\hline Antiviral use & $1054 / 2144(49.2 \%)$ \\
\hline Corticosteroid use & $548 / 2107(26 \%)$ \\
\hline Intravenous immunoglobulin use & $275 / 1859(14.8 \%)$ \\
\hline Oxygen & $1061 / 2063(51.4 \%)$ \\
\hline Continuous renal replacement therapy & $42 / 1620(2.6 \%)$ \\
\hline
\end{tabular}

\section{Epidemiological and clinical characteristics}

A total of 2747 patients had a confirmed diagnosis of COVID-19 across these 21 studies, the majority of the data (14/21 of the studies) were from China. The mean age of the total study cohort was $48 \pm 10.8$ (SD) years. 1599/2736 (58.4\%) were male. 909/1929 (47.1\%) patients had a history of direct exposure with the infected person, while $371 / 1540$ (24.1\%) had a recent history of travel to China. We found that most common clinical symptoms of COVID-19 patients were fever (2209/2438; 90.6\%), cough (1656/2438; 67.9\%), myalgia or fatigue $(1179 / 2438 ; 48.3 \%)$, sputum production or expectoration $(602 / 2438 ; 24.7 \%)$ and dyspnea (554/2438; 22.7\%). Other clinical symptoms included headache (235/2438; 9.6\%), sore throat (192/2438; $7.9 \%)$, nausea or vomiting (124/2438; $5.1 \%)$, diarrhea (121/2438; 4.9\%), nasal congestion (25/2438; 1\%) and hemoptysis (14/2438; 0.57\%). Most common laboratory findings were increased C-reactive protein (CRP) levels $(707 / 1388 ; 51 \%)$, increased lactate dehydrogenase (LDH) levels (700/1678; 41.7\%), lymphocytopenia (634/1737; 36.5\%), increased D-dimer levels (457/1590; $28.7 \%)$, and leukocytopenia (464/1668; 27.8\%). Hypertension (422/2188; 19.3\%), smoking (189/1678; $11.3 \%)$, diabetes mellitus $(217 / 2169 ; 10 \%)$, and cardiovascular diseases (166/2244; 7.4\%) were the most common coexisting comorbidities. 1321/1598 (82.7\%) patients had abnormal chest computed tomography scan findings, with 1445/2197 (65.7\%) patients had bilateral lungs affected, and 975/1637(59.5\%) patients showed ground-glass opacity. 1406/2042 (68.8\%), 1054/2144 (49.2\%), 548/2107 (68.8\%) and 275/1859 (14.8\%) patients with confirmed COVID-19 were given antibiotics, antiviral medicines, corticosteroid and intravenous immunoglobulin as treatment respectively. Oxygen was administered in 1061/2063 (51.4\%) patients. 42/1620 (2.6\%) patients required continuous renal replacement therapy. Common complications of COVID-19 infection were pneumonia (1412/1722; 82\%), cardiac complications $(136 / 514 ; 26.4 \%)$, acute respiratory distress syndrome (291/1842; 15.7\%), secondary infection (44/393; $11.2 \%)$, and septic shock (66/1527; 4.3\%) (Table 2).

\section{Patients' outcomes}

Overall, 188/2243 (8.4\%) patients had died and $370 / 1813$ (20.4\%) patients had recovered. 322/2090 (15.4\%) patients required ICU admission and 304/2035 (14.9\%) patients required mechanical ventilation (Table 2).

\section{Secondary outcomes}

\section{Case fatality rate (CFR)}

On January 22, 2020, CFR for China was 3.1\% which remained between 2\%-4\% until March 31. On March 4, CFR for USA was $7.38 \%$ which declined to $2.06 \%$ 
Table 2. Continued

\begin{tabular}{lc} 
Total number of Conflimed Cases from Articles Reviewed & N = 2747 \\
Complications: & \\
Pneumonia & $1412 / 1722(82 \%)$ \\
\hline Acute respiratory distress syndrome & $291 / 1842(15.7 \%)$ \\
\hline Septic shock & $66 / 1527(4.3 \%)$ \\
\hline Cardiac complication & $136 / 514(26.4 \%)$ \\
\hline Secondary infection & $44 / 393(11.2 \%)$ \\
\hline Other & $210 / 1600(13.1 \%)$ \\
Outcomes: & $188 / 2243(8.4 \%)$ \\
\hline Deaths & $370 / 1813(20.4 \%)$ \\
\hline Recovery & $322 / 2090(15.4 \%)$ \\
\hline Intensive care unit (ICU) admissions & $304 / 2035(14.9 \%)$ \\
\hline Mechanical ventilation requirement
\end{tabular}

on March 31. Initially in Italy, on February 21 CFR was $5 \%$, reduced to $2.01 \%$ on March 1 , then increasing to $11.7 \%$ on March 31. Spain's CFR was $0.61 \%$ on March 3 which increased to $8.82 \%$ on March 31 . For South Korea, CFR was $0.96 \%$ on February 20, slowly reaching $1.66 \%$ on March 31. CFR in India was $1.61 \%$ on March 11 , which has increased to $2.51 \%$ on March 31 . Germany had a CFR of $0.17 \%$ on March 9 which increased to 1.08\% on March 31. In Iran, on Feb 19 CFR was almost $100 \%$ which reduced to $3.3 \%$ on March 3 with larger numbers of cases and from then it has increased and reached $6.5 \%$ on March 31 . The changes in the country-specific CFR are plotted in Figure S2 in the Online Supplementary Document.

\section{Strength of association between deaths and cases to predict CFR (Predictive modeling)}

Several models, including a simple linear regression, exponential and polynomial (quadratic) growth models, were used to determine the type of association between cumulative deaths and cumulative cases to predict CFR (Table 3). The polynomial growth model had the best fit (higher $\mathrm{R}^{2}$ ) and indicates that for all countries the death rate increases with the number of cases, and this increase is steeper than a linear relationship. Interestingly, while for the USA, Italy, Iran, Spain, and India this association is always positive, for China, South Korea, and Germany the initial slope is negative but then is reversed as the number of cases continues to increase (Figure 1).

Table 3. Country-specific strength of association between deaths and cases (predicted case fatality rate, CFR)

\begin{tabular}{|c|c|c|c|c|c|c|c|}
\hline Countay & $\begin{array}{l}\text { Pearson } \\
\text { correlation } \\
\text { (B) }\end{array}$ & 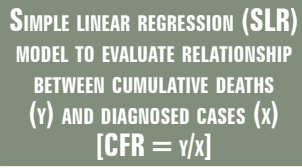 & $\begin{array}{l}\text { CoEFFICIENT OF } \\
\text { DEIERMINATION } \\
\text { (R2) FOR SLR } \\
\text { MODEL }\end{array}$ & $\begin{array}{l}\text { EXPOMENTIAL GROWTH (EG) } \\
\text { MODEL TO EVALUATE RELATIONSHIP } \\
\text { BETWEEN CUMULATIVE DEATHS } \\
\text { ( } \mathrm{Y} \text { ) AND DIAGNOSED CASES (X), } \\
\text { [CFR }=\mathrm{v} / \mathrm{X} \text { ] }\end{array}$ & $\begin{array}{l}\text { COEFFICIENT OF } \\
\text { DETERMINATION } \\
\text { (R2) FOR EG } \\
\text { MODEL }\end{array}$ & 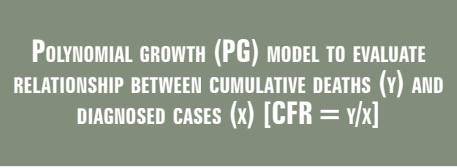 & $\begin{array}{l}\text { CoEfFicient OF } \\
\text { DEtermination } \\
\text { (R2) FOR PG } \\
\text { MODEL }\end{array}$ \\
\hline USA & 0.99 & $y=0.0182 x-48.4$ & 0.979 & $y=29.002 e 0.00003 x$ & 0.663 & $y=0.00000006 \times 2+0.0097 x+21.651$ & 0.999 \\
\hline Germany & 0.96 & $y=0.0093 x-68.1$ & 0.915 & $y=6.4584 e 0.00008 x$ & 0.872 & $y=0.0000002 \times 2-0.0006+10.24$ & 0.996 \\
\hline China & 0.96 & $y=0.0399 x-309$ & 0.924 & $y=83.267 e 0.00005 x$ & 0.907 & $y=0.0000005 \times 2-0.0079 x+183.16$ & 0.969 \\
\hline Italy & 0.99 & $y=0.1094 x-399.7$ & 0.986 & $y=59.277 e 0.00007 x$ & 0.673 & $y=0.00000057 x 2+0.0642 x-58.624$ & 0.999 \\
\hline Iran & 0.99 & $y=0.0721 x-87.4$ & 0.976 & $y=33.548 e 0.0001 x$ & 0.727 & $y=0.00000001 x 2+0.0716 x-85.485$ & 0.976 \\
\hline Spain & 0.99 & $y=0.0859 x-317$ & 0.987 & $y=40.211 e 0.00007 x$ & 0.668 & $y=0.0000004 x 2+0.0533 x-88.124$ & 0.999 \\
\hline South Korea & 0.88 & $y=0.0133 x-18$ & 0.779 & $y=3.7164 e 0.0004 x$ & 0.923 & $y=0.000003 x 2-0.0148 x+18.415$ & 0.945 \\
\hline India & 0.99 & $y=0.0257 x-1.4$ & 0.980 & $y=1.8001 e 0.0026 x$ & 0.892 & $y=0.000005 x 2+0.019 x-0.285$ & 0.985 \\
\hline
\end{tabular}
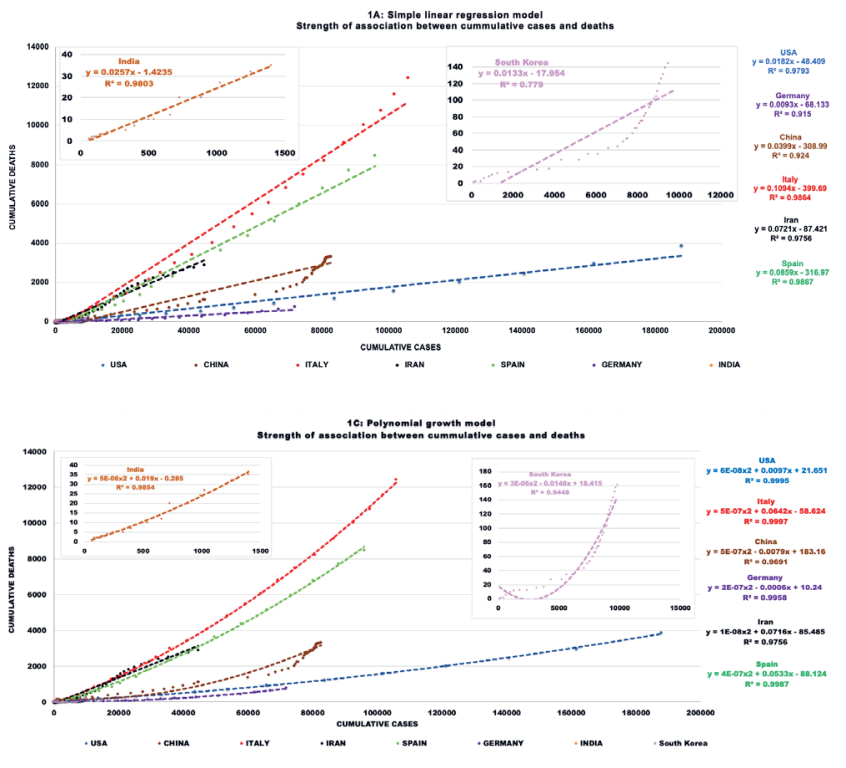

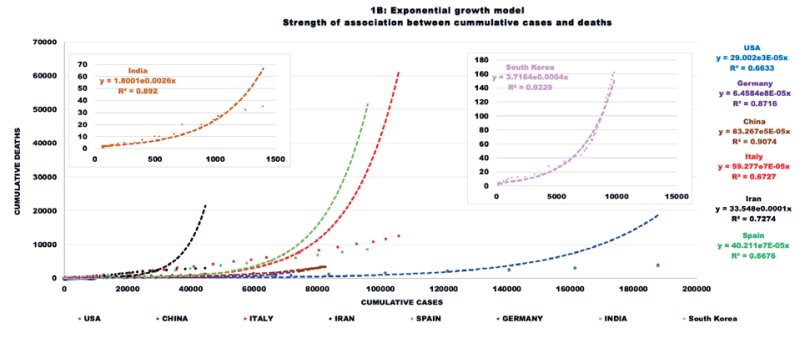

Figure 1. Modeling to determine the type of association between cumulative deaths and cumulative cases to predict case fatality rate (CFR). Panel A. Simple linear regression. Panel B. Exponential growth model. Panel C. Polynomial (quadratic) growth model. 


\section{COVID-19 specific death rate}

COVID-19 specific death rates (per 100000 population) for individual countries are presented in Figure S3 in the Online Supplementary Document. In USA, cumulative COVID-19 specific death rate is steadily increasing and has reached 1.17 , lower than in other countries like Italy (20.55 : exponentially increasing), Iran (3.45:constantly increasing), and Spain (16.10:exponentially increasing) but higher than China (0.23:almost steady), Germany (0.925:constantly increasing), South Korea (0.316:slowly increasing) and India (0.002:constantly increasing) as of April 1 (Figure S3A in the Online Supplementary Document). The daily COVID-19 specific death rate is highest in Spain (daily 1.6 deaths per 100000 population) and Italy (daily 1.38 deaths per 100000 population) followed by USA (daily 0.27 deaths per 100000 population) (Figure S3B in the Online Supplementary Document).

\section{Doubling time}

The county-specific timeline of doubling time for cases and deaths is shown in Table 4 and the increment in cases and deaths are plotted in (Figure 4 in the Online Supplementary Document).

Table 4. Country specific doubling time for cases and deaths

Dates $\quad$ Doubung tIME fOR cases (Davs)

USA [First case reported: January 22, 2020; First death reported: February 29, 2020]:

\begin{tabular}{lcccc}
\hline January 22-January 26 & 2 & February 29-March 2 & 2 \\
\hline January 26-February 3 & 8 & March 2-March 5 & 3 \\
\hline February 3-February 24 & 21 & March 5- March 15 & 5 \\
\hline February 24-March 2 & 7 & March 18-March 29 & 3 \\
\hline March 2-March 30 & $2-4$ & 2-3 \\
\hline
\end{tabular}

China [First case reported: December 31, 2019; First death reported: January 11, 2020]:

\begin{tabular}{|c|c|c|c|}
\hline January 22 - January $25^{*}$ & 3 & January 22 - February $2 *$ & $2-3$ \\
\hline January 25 - January 29 & 2 & February 2 - February 6 & 4 \\
\hline January 29 - February 4 & 3 & February 6 - February 13 & 7 \\
\hline February 4 - February 13 & 9 & February 13 - February 26 & 13 \\
\hline February $13-$ March $31 \dagger$ & $>47$ & February $26-$ March $31 \dagger$ & $>34$ \\
\hline \multicolumn{4}{|c|}{ Italy [First case reported: January 31, 2020; First death reported: February 21, 2020]: } \\
\hline January 31 - February 21 & 21 & February 21 - February 24 & $1-2$ \\
\hline February 21 - February 29 & $1-2$ & February $24-$ March 15 & $2-4$ \\
\hline February 29 - March 15 & $3-4$ & March 15 - March 20 & 5 \\
\hline March 15 - March 20 & 5 & March 20 - March 26 & 6 \\
\hline March 20 - March 29 & 9 & March $26-$ March $31^{+}$ & $>5$ \\
\hline \multicolumn{4}{|c|}{ Iran [First case reported: February 19, 2020; First death reported: February 19, 2020]: } \\
\hline February $19-$ March 2 & $1-2$ & February 19 - February 25 & 2 \\
\hline March 2 - March 5 & 3 & February 25 - February 28 & 3 \\
\hline March 5 - March 9 & 4 & February 28 - March 15 & 4 \\
\hline March 9 - March 16 & 7 & March $15-$ March 21 & 6 \\
\hline March 16 - March 27 & 11 & March $21-$ March $31 \dagger$ & $>10$ \\
\hline \multicolumn{4}{|c|}{ Spain [First case reported: February 1, 2020; First death reported: March 3, 2020]: } \\
\hline February 1 - February 9 & 8 & March 3 - March 15 & $1-2$ \\
\hline February 9 - February 25 & 16 & March 15-March 24 & 3 \\
\hline February 25 - March 13 & $1-3$ & March 24-March 28 & 4 \\
\hline March 13 - March 31 & $4-6$ & March $28-$ March $31 \dagger$ & $>3$ \\
\hline \multicolumn{4}{|c|}{ Germany [First case reported: January 27, 2020; First death reported: March 9, 2020]: } \\
\hline January 27 - February 1 & $1-4$ & March $9-$ March 13 & 4 \\
\hline February 1 - February 11 & 10 & March 13 - March 28 & 3 \\
\hline February $11-$ February 27 & 16 & March $28-$ March $31 \dagger$ & $>3$ \\
\hline February 27 - March 19 & $2-4$ & & \\
\hline March 19 - March 29 & 5 & & \\
\hline \multicolumn{4}{|c|}{ South Korea [First case reported: January 20, 2020; First death reported: February 20, 2020]: } \\
\hline January 22 - January 31 & $1-4$ & February 20 - February 21 & 1 \\
\hline January 31 - February 6 & 6 & February 20 - February 26 & $2-3$ \\
\hline February 6 - February 20 & 14 & February 26 - March 2 & 5 \\
\hline February 20 - March 1 & $1-3$ & March 2 - March 11 & 9 \\
\hline March 1 - March 9 & 8 & March $11-$ March 24 & 13 \\
\hline March $9-$ March $31 \dagger$ & $>21$ & March $24-$ March $31 \dagger$ & $>7$ \\
\hline
\end{tabular}


Table 4. Continued

India [First case reported: January 30, 2020; First death reported: March 11, 2020]

\begin{tabular}{lcll} 
January $30-$ February 2 & 3 & March 11-March 13 & 2 \\
\hline February 2- March 2 & 29 & March 13-March 19 & 6 \\
\hline March 2 - March 4 & 2 & March 19-March 23 & 4 \\
\hline March 4 - March 20 & $5-6$ & March 23 - March 26 & $>5$ \\
\hline March 20 - March 23 & 3 & March 26 - March 31† & \\
\hline March 23 - March 29 & 6 & & \\
\hline
\end{tabular}

*Data on daily cases and deaths are unavailable before January 22, 2020.

$\uparrow$ Deaths or cases have not yet doubled from the previous respective dates.

\section{Interventions}

Table 5 summarizes the different interventions adopted by different countries in an effort to mitigate the spread of the COVID-19 virus.

Table 5. Measures taken by various countries to prevent spread and mitigate the risk United States of America (USA)

29 January White House Coronavirus Task Force established to monitor, prevent, contain, and mitigate the spread of the pandemic in the USA [37] 31 January Declared public health emergency[38]; Travel restrictions placed on entry from China [38]

6 March The President signed the Coronavirus Preparedness and Response Supplemental Appropriations Act (CPRSA) providing \$8.3 billion in emergency funding for federal agencies to respond to the outbreak [39]

All 50 states are permitted to perform tests by a doctor's approval, from the CDC or commercial laboratories[40] and appointment of

12 March Admiral Brett Giroir of the U.S Public Health Service to oversee testing, funding for two companies developing rapid tests, and a hotline to help laboratories find needed supplies [41]

13 March National emergency was declared, making federal funds available to respond to the crisis [42], Drive-through testing began [43]

16 March President Trump's Coronavirus guidelines for America [44]

19 March Lockdown in California [45]

20 March Barred entry of foreign nationals who had been to 28 European countries within last 14 days [46]

22 March Nationwide schools closed [47], Lockdown in New York [45]

27 March A US\$2 trillion coronavirus stimulus bill was passed and signed by the President [48]

30 March More than half of US states underwent lockdown [45]

China:

22 January Response to Public Health Emergency launched by Hubei [49]

The Central government of China imposed a lockdown in Wuhan and other cities in Hubei province; Public transport suspended. The

23 January Wuhan airport, railway stations and metro were closed, not allowing residents to leave the city without permission [50]; Public Health Emergency response announced by mainland province of Zhejiang [51]

29 January Mainland China has initiated Public Health Emergency response [52]; Quarantined whole Hubei Province [53]; Curfew laws implemented in Huanggang,Wenzhou and other mainland cities [54]

South Korea:

4 February An unlicensed Covid-19 test authorized by the Korea Centers for Disease Control and Prevention (CDC) [55]; Travel denied to foreign nationals from Hubei Province into South Korea [56]

23 February All kindergartens, elementary schools, middle schools, and high schools were announced to delay the semester start [57]

26 February Entire country opened drive-through testing [58]

Italy:

31 January State of emergency declared, flights to and from China suspended [59]

22 The Council of Ministers announced a new decree-law to quarantining more than 50000 people from 11 different municipalities in Northern Italy [60]

4 March Nationwide schools and universities closed [61]

10 March Prime Minister imposed Nationwide quarantine lockdown [62]

11 March All commercial activities except pharmacies and supermarkets ordered to shut down [63]; €25billion allocated by the government [64]

1 April Drive-through testing began [65]

Iran:

22 February All concerts and other cultural events cancelled for one week by Ministry of Islamic Culture and Guidance [66]; Closure of educational institutions in several cities and provinces announced by the Ministry of Health and medical education [67]

5 March Checkpoints placed between cities to limit travel [68]

16 March Fatima Masumeh Shrine, Jamkaran Mosque in Qom city, and Imam Reza Shrine in Mashhad closed [69] 
Table 5. Continued

\begin{tabular}{|c|c|}
\hline \multicolumn{2}{|r|}{ el } \\
\hline 28 February & $\begin{array}{l}\text { New health security measures enacted to regulate air and sea travel that required passengers from China, South Korea, Japan, Italy and } \\
\text { Iran to report their health status before entry [70]; Federal police stepped up checks within } 30 \mathrm{~km} \text { of the border [70] }\end{array}$ \\
\hline 16 March & $\begin{array}{l}\text { Bavaria declared a state of emergency for } 14 \text { days and measures to limit public movement and additional funds for medicine supplies } \\
\text { were introduced [71]; All flights from Iran and China stopped by German Ministry of Transport [72]; Travelling in coaches, attending } \\
\text { religious meetings, visiting playgrounds or engaging in tourism prohibited [73] }\end{array}$ \\
\hline 17 March & $\begin{array}{l}\text { Immediate travel ban into the European Union for } 30 \text { days for non-EU citizens was announced by Merker [74] followed by widening } \\
\text { travel restrictions to EU citizens from Italy, Switzerland, Denmark, Luxembourg and Spain [75] }\end{array}$ \\
\hline 20 March & Bavaria became the first state to declare a curfew [76] \\
\hline 22 March & $\begin{array}{l}\text { Gathering of more than } 2 \text { people forbidden by the government for at least } 2 \text { weeks with a minimum distance of } 1.5 \mathrm{~m} \text { between peo- } \\
\text { ple in public [77] }\end{array}$ \\
\hline \multicolumn{2}{|r|}{. } \\
\hline 10 March & All direct flights from Italy to Spain cancelled [78] \\
\hline 13 March & Bars, restaurants and "non-alimentary" shops ordered to shut down by Government of the Community of Madrid [79] \\
\hline 15 March & Nationwide lockdown imposed by the Spanish government [80] \\
\hline 16 March & Spanish government announced the closing of its land borders [81] \\
\hline \multicolumn{2}{|l|}{ India: } \\
\hline 3 March & Issuing of new visas and visas already issued for nationals of Italy, Iran, South Korea, and Japan suspended by the Indian government [82] \\
\hline 4 March & Compulsory screening of all international passengers arriving in India announced by the Minister of Health and Family Welfare [83] \\
\hline 11 March & $\begin{array}{l}\text { All visas to India suspended by the government; All Indian nationals coming from COVID-19 hit nations after } 15 \text { February needed to } \\
\text { be quarantined for } 14 \text { days [82] }\end{array}$ \\
\hline 15 March & $\begin{array}{l}65 \text { laboratories of the Department of Health Research and the Indian Council of Medical Research (DHR-ICMR) started testing samples } \\
\text { of people who exhibited flu-like symptoms and samples from patients without any travel history or contact with infected persons [84] }\end{array}$ \\
\hline 17 March & The Government of India issued an advisory urging all states to take social distancing measures as a preventive strategy [82] \\
\hline 22 March & Janata curfew (people's curfew) imposed [82] \\
\hline 23 March & Use of hydroxychloroquine for treatment of COVID19 for high-risk cases recommended by National Task Force constituted by ICMR [85] \\
\hline 25 March & Nationwide lockdown for 21 days [86]; Indian airspace closed [87] \\
\hline 26 March & Finance minister announced US\$24 billion stimulus package [88] \\
\hline
\end{tabular}

Infection rate at the beginning of the major intervention (nationwide closure of school or major lockdown): Infection rate (number of diagnosed cases per 100000 population) for the USA (March 22: 10.04; March 30: 48.81) was higher than China (January 23: 0.42), South Korea (February 23: 1.17) and India (March 25: 0.048). Infection rates were higher in Italy (March 10: 20.61), Iran (March 16: 17.85), Spain (March 14: 13.67), and Germany (March 22: 29.69).

Travel restrictions: China (January 23: Wuhan public transport) followed by Italy (January 31: all flights) and USA (January 31: flights from China; March 20: flights from European Union), South Korea (February 4: Hubei Foreigners), Iran (March 5: checkpoints between cities), Spain (March 10: all flights; March 16: closure of land borders), Germany (March 16: flights from China and Iran; March 17: European Union), India (March 4: mandatory screening of international passengers; March 11: suspension of all visas; March 25: closing of airspace).

Quarantines, lockdowns, and social distancing measures: China (January 29: Hubei, some cities of China) followed by Northern Italy (February 22). Lockdown measures were put in China (January 23: Wuhan, other cities of Hubei), Italy (March 10), Spain (March 14), California (March 19), Bavaria-Germany (March 20), New York (March 22) and India (March 25). Nationwide educational institutes closure: Iran (February 22), Italy (March 4) and USA (March 22). All social and religious gathering canceled: Iran (February 22: concerts and cultural events; March 16: mosques and shrines), Germany (March 16; March 22: no gathering of $>2$ people).

Other actions: China: public health emergency response (January 22: Hubei; January 29:mainland China); Italy: state of emergency (January 31); USA: White House Coronavirus Task Force (January 29), public health emergency (January 31), US\$ 8.3 billion emergency funding (March 6), national emergency (March 13), $\$ 2$ trillion stimulus bill (March 27); Spain: state of alarm (March 14); Bavaria-Germany: state of emergency (March 16); India: US\$ 24 billion stimulus package (March 26).

Testing: The drive-through centers are operational in South Korea from February 26, USA from March 13, and Italy from April 1. As of April 1, cumulative tests conducted (per million population) in the USA (3470) are higher than Iran (952), China (222), India (35) and lower than Germany (11 127), Italy (9156), South Korea (8184), Spain (7593). The tests conducted (per day) in the USA (100989) are higher than Italy (34455), South Korea (10983), India (5163) and Germany (5902) [89,90]. 


\section{Impact of strict interventions on predicted days to reach peak number of diagnosed cases}

Table 6 mentions the predicted dates of the peak number of cases based on strict interventions. In China and South Korea, it took 16-21 days and 11-14 days respectively in order to achieve the peak of the pandemic before the new number of cases began to decline. We have used a 16-21 days post-interventional model to calculate the peak of the pandemic keeping in mind the effect of China's model of interventions.

Table 6. Country-specific predicted dates of peak numbers of cases according to strict interventions

\begin{tabular}{|c|c|c|c|}
\hline Country & StRICT INTERVENTIONS (LockDOWNS AND ClOSURE OF EDUCATIONAL INSTITUTES) & DaYs to ReAch PEAK (DAYS) & Peak number of cases* \\
\hline China & January 23-January 29 & $16-21$ & February 13-February 14 \\
\hline South Korea & February 18-February 23 & $11-14$ & February 29-March 3 \\
\hline \multicolumn{4}{|c|}{ Predicted dates of peak numbers of cases:* } \\
\hline Italy & March 4-March 11 & $16-21$ & March 20-April 1 \\
\hline Iran & March 16 & $16-21$ & April 1-April 6 \\
\hline Spain & March 14 & $16-21$ & March 30-April 4 \\
\hline Germany & March 22 & $16-21$ & April 7-April 12 \\
\hline USA & March 22-March 30 & $16-21$ & April 7-April 20 \\
\hline India & March 25 & $16-21$ & April 10-April 15 \\
\hline
\end{tabular}

* Predicted dates based on implementation of strict lockdown of non-essential businesses, school, and public gathering. We have taken 16-21 days, keeping in mind the effect of China's model of interventions.

\section{DISCUSSION}

COVID-19 has significantly impacted the entire world both socially and economically. The rapid human-to-human transmission has posed a great public health threat. Across 21 studies included in this review, we found 2747 confirmed cases of COVID-19 with the majority of the published studies from China. $47 \%$ of the cases had a history of direct exposure or being exposed to the seafood market in Wuhan, $44 \%$ were China residents and $24 \%$ had a travel history to China. Initially the virus was limited to only Wuhan and despite travel restriction, the virus continued to spread across the world at a rapid rate from China, likely due to asymptomatic transmission in the initial stages of the outbreak with a median incubation period of only 5 days [7,17], before travel restrictions. The COVID-19 cases are increasing exponentially but underestimated due to mild symptoms in a portion of cases, long incubation periods, and shortage of testing kits. In concurrence with other studies [18,29], we found that clinical characteristics of COVID-19 are similar to those of SARS and influenza virus. Fever (91\%), cough (68\%) and myalgia or fatigue (48\%) were the most prominent symptoms. $24 \%$ of patients reported dyspnea and sputum production/expectoration. Major comorbidities were hypertension, smoking, diabetes mellitus, and cardiovascular disease. Patients with these comorbidities are at high risk for complications including pneumonia, ARDS and cardiovascular complications. We found that patients had increased inflammatory markers including elevated CRP in 50\%, lymphopenia in 36\% and elevated ESR in 25\% which is similar to other respiratory infections (SARS, influenza). Few studies [18,91], have reported abnormal liver function in COVID-19 patients, and we found 20\% of patients had elevated ALT and AST. Additionally, increased LDH (42\%), D-dimer(29\%) may indicate the severity of the disease[92]. Some studies have also reported elevated neutrophil count and cytokine storm induced by virus leading to coagulation activation and sustained inflammatory response [22] associated with higher mortality [29].

There is no proven therapy available as of now for COVID-19. Few studies like Wang et al. showed that remdesvir and hydroxychloroquine have in vitro efficacy in inhibiting the SARS-CoV-2 virus [93], Gao et al. suggest higher efficacy of hydroxychloroquine compared to supportive treatment [94] and Gautret et al. suggest enhanced efficacy with azithromycin and hydroxychloroquine combination [95]. Large scale clinical trials for these drugs are under way. 50\% patients received oxygen and antibiotics (69\%), antivirals (49\%) and steroids (26\%) as supportive therapies. The prognosis of patients after receiving these treatments is not yet clear. In people with compromised immune systems such as older age, HIV, malignancy, diabetes, chronic pulmonary disease if treated promptly with antibiotics, convalescent plasma to increase the immune support might reduce the risk of complications and mortality [96].

In our analysis, 15\% of the patients required ICU admission, 15\% needed mechanical ventilation, $8 \%$ died and 20\% recovered and were discharged from the hospital. These findings are consistent with Guan et al. and Wang et al that present similar rates [11,22]. Currently in the USA, COVID-19 is in the acceleration phase surpassing China and Italy, and a National emergency was declared by the President, but the 
duration and severity may vary depending on the virus characteristics and public health response [97]. If confirmed cases continue to grow with this trend, soon the COVID-19 pandemic will cause shortages of ventilators. As per Institute for Health Metrics and Evaluation (IHME) projections, on a peak day in the USA, there would be a shortage of ICU beds by 19863 and a need of 31782 ventilators [98]. The growing number of cases will place a burden on the current capacity of hospitals and hence it is essential to develop and implement strategies to mitigate the gap by increasing capacity and fair allocation of available resources.

As of March 31, CFR in Italy was $11.75 \%$ and $4.01 \%$ in China. According to Onder et al. [99], CFR stratification by age, shows similar rates for $0-60$ years $(0 \%-3.6 \%)$ but higher in $>70$ years $(8 \%-20.2 \%)$. This difference might be due to high CFR reported in people $>90$ years in Italy and no data from China for the same age group [99]. Other reasons might be demographics differences between two countries ( $\geq 65$ years population: Italy-22.8\% vs China-10.9\%), overwhelming health care system, and shortage of ICU beds and ventilators, which might lead to prioritizing treatment to younger and otherwise healthy patients over older patient [100]. In our analysis CFR in Italy increased from 1.94\% on February 23 to $8.57 \%$ on March 20, possibly due to the implementation of a strict policy of testing only suspected cases with severe symptoms [99]. Though widespread and drive-through testing is becoming more available in USA, cumulative tests conducted per million population lags behind compared to Germany, Italy, South Korea, and Spain. Our data driven polynomial growth model predicts more deaths in future with an increase in cases in USA [98], Italy, Iran, Spain, and India. As per our model predictions, doubling time of cases in the USA, Germany and India is decreasing suggesting that they are inching towards the peak. Different countries undertook interventions at different points in the timeline of spread of virus. The infection rates in the USA, Italy, Iran, Spain, and Germany were higher when they undertook substantial measures compared to China, South Korea, and India, suggesting a delayed response and failure to undertake timely measures. The aforementioned timelines for peaks look optimistic because multiple other factors may influence the trajectory of spread, ie, population density, economy, demographics, health care, religious beliefs, and legislation. For instance, despite the growing number of cases, Iran continued to keep its shrines open to pilgrims for a long time, but recently closed them, and no stringent curfew laws were imposed. Also, many states in USA have still not implemented strict quarantine measures. Such practices can seriously impede the efforts at containing the spread and skew the projection in many ways. Restrictions have neither been homogeneously imposed nor simultaneously adopted throughout the country, making it difficult to predict the exact model of the spread.

Also, COVID-19 testing capacity of the nations are limited and the true number of the infected people might have been higher than the estimated numbers at the time of our analysis. Hence, an early phase COVID- 19 specific death rate would be a better estimate than CFR to compare the severity of the disease. Many factors contribute to the accurate estimation of CFR such as testing capacity, care seeking and lack of understanding of the proportion of asymptomatic and pre symptomatic cases [101,102]. Limited knowledge of these factors in the early COVID-19 phase might have contributed to overestimation of CFR in our study. The use of serological testing for presence of IgM or IgG antibodies against SARS-CoV-2 will provide a better estimate of cumulative prevalence of COVID 19 infection [103]. As recommended by WHO, measuring the seroprevalence of antibodies to COVID-19 is crucial and will contribute to determine accurate CFR and help plan adequate public health response [104].

\section{Limitations, strengths, and future directions}

The research on COVID-19 is rapidly evolving and new publications are becoming available daily. The majority of the epidemiologic data are coming from single center with limited sample sizes. To overcome this limitation and provide a global view of the COVID-19 pandemic, we have analyzed data on over 2500 patients from 21 peer-reviewed studies. As a result, we provided more generalizable estimates of laboratory findings, clinical symptoms and complications of COVID-19 patients. We have included data from several countries/regions; however, one limitation is that the majority of cohorts are from China, and as more data from other countries become available, additional meta-analyses would be essential. This is the first study rigorously tracking the timing of government interventions across multiple countries; however, as mentioned earlier, the adherence to those interventions could vary from one country to another, making the projections of the potential effectiveness challenging. We have not evaluated the duration of strict interventions in all these countries. The population prevalence data are based on the symptomatic patients with confirmed RT-PCR testing. Since some patients can be infected and present mild or no symptoms, or have not undergone RT-PCR testing, serological antibody testing in the future may allow a 
more accurate understanding of the disease prevalence and death rates. Despite all the limitations, this is the first study in our knowledge, highlighting and explaining epidemiological indicators, testing capacity, interventions, and expected burden of the COVID 19 at early phase.

\section{CONCLUSIONS}

We have reviewed the burden of this pandemic and steps taken by the governments of different countries. Though the governments can continue strict lockdowns, it is not a long-term solution. Good hand hygiene, widespread testing, detection and isolation of new cases, rigorous contact tracing in low-prevalence settings, early vaccine development and its quick distribution, strengthening the overburdened health care system, and protecting frontline health care workers may help to gradually relax the strict lockdowns and cope with COVID-19 pandemic. This would only be possible by a collective approach undertaken by responsible governments, wise strategy implementation, and receptive populations. The future studies should be focused on identifying accurate indicators to mitigate the effect of underestimation or overestimation of COVID-19 burden. Close monitoring of such indicators in highly affected countries is very crucial to evaluate the potential fatality if the second wave of pandemic occurs.

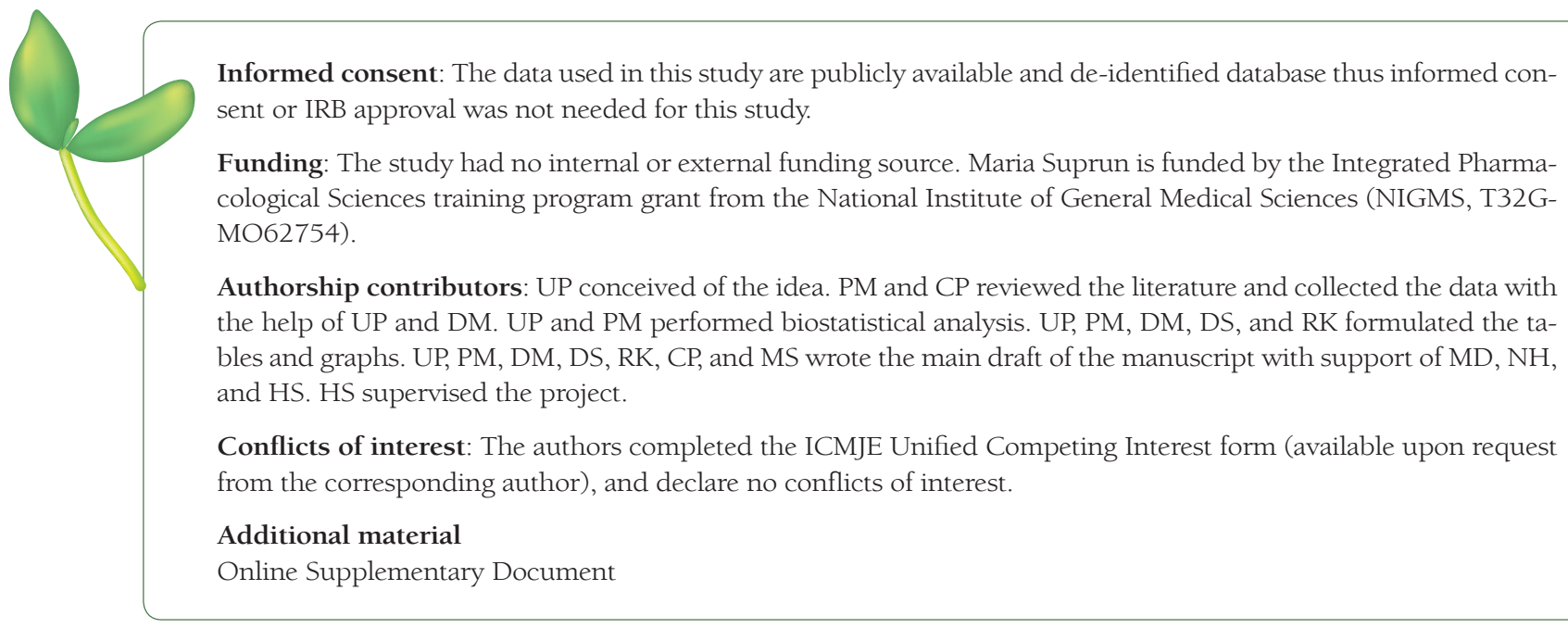

Informed consent: The data used in this study are publicly available and de-identified database thus informed con. the help of UP and DM. UP and PM performed biostatistical analysis. UP, PM, DM, DS, and RK formulated the tables and graphs. UP, PM, DM, DS, RK, CP, and MS wrote the main draft of the manuscript with support of MD, NH,

Conflicts of interest: The authors completed the ICMJE Unified Competing Interest form (available upon request from the corresponding author), and declare no conflicts of interest.

dditional material

Online Supplementary Document

1 WHO Director-General's opening remarks at the media briefing on COVID-19 - 11 March 2020. 2020. Available: https://www.who.int/dg/speeches/detail/who-director-general-s-opening-remarks-at-the-media-briefing-on-covid-1911-march-2020. Accessed 9 April 2020.

2 COVID-19 CORONAVIRUS PANDEMIC. 2020. Available: https://www.worldometers.info/coronavirus/\#countries. Accessed: 1 April 2020.

3 Coronavirus COVID-19 Global Cases by the Center for Systems Science and Engineering (CSSE) at Johns Hopkins University. (JHU). 2020. Available: https://coronavirus.jhu.edu/map.html. Accessed: 1 April 2020.

4 Novel Coronavirus - China. 2020. Available: https:/www.who.int/csr/don/12-january-2020-novel-coronavirus-china/ en/. Accessed 9 April 2020.

5 Holshue ML, DeBolt C, Lindquist S, Lofy KH, Wiesman J, Bruce H, et al. First Case of 2019 Novel Coronavirus in the United States. N Engl J Med. 2020;382:929-36. Medline:32004427 doi:10.1056/NEJMoa2001191

6 Guan WJ, Ni ZY, Hu Y, Liang WH, Ou CQ, He JX, et al. Clinical Characteristics of Coronavirus Disease 2019 in China. N Engl J Med. 2020;382:1708-20. Medline:32109013 doi:10.1056/NEJMoa2002032

7 Linton NM, Kobayashi T, Yang Y, Hayashi K, Akhmetzhanov AR, Jung S-M, et al. Incubation Period and Other Epidemiological Characteristics of 2019 Novel Coronavirus Infections with Right Truncation: A Statistical Analysis of Publicly Available Case Data. J Clin Med. 2020;9:538. Medline:32079150 doi:10.3390/jcm9020538

8 Lauer SA, Grantz KH, Bi Q, Jones FK, Zheng Q, Meredith HR, et al. The Incubation Period of Coronavirus Disease 2019 (COVID-19) From Publicly Reported Confirmed Cases: Estimation and Application. Ann Intern Med. 2020;172:57782. Medline:32150748 doi:10.7326/M20-0504

9 Interim Guidelines for Collecting, Handling, and Testing Clinical Specimens from Persons for Coronavirus Disease 2019 (COVID-19). 2020. Available: https://www.cdc.gov/coronavirus/2019-ncov/lab/guidelines-clinical-specimens.html. Accessed: 9 April 2020.

10 Corman VM, Landt O, Kaiser M, Molenkamp R, Meijer A, Chu DKW, et al. Detection of 2019 novel coronavirus (2019-nCoV) by real-time RT-PCR. Euro Surveillance. 2020;25:2000045. Medline:31992387 doi:10.2807/1560-7917. ES.2020.25.3.2000045 
11 Guan WJ, Ni ZY, Hu Y, Liang WH, Ou CQ, He JX, et al. Clinical Characteristics of Coronavirus Disease 2019 in China. J Infect. 2020;80:656-65. Medline:32283155 doi:10.1016/j.jinf.2020.03.041

12 The Novel Coronavirus Pneumonia Emergency Response Epidemiology Team. The Epidemiological Characteristics of an Outbreak of 2019 Novel Coronavirus Diseases (COVID-19) - China, 2020. China CDC Weekly. 2020;2:113-22.

13 Zhang S, Diao M, Yu W, Pei L, Lin Z, Chen D. Estimation of the reproductive number of novel coronavirus (COVID-19) and the probable outbreak size on the Diamond Princess cruise ship: A data-driven analysis. Int J Infect Dis. 2020;93:2014. Medline:32097725 doi:10.1016/j.ijid.2020.02.033

14 COVID-19 Coronavirus Tracker. 2020. Available: https://www.kff.org/global-health-policy/fact-sheet/coronavirus-tracker/. Accessed: 1 April 2020.

15 Coronavirus disease (COVID-2019) situation reports. 2020. Available: https://www.who.int/emergencies/diseases/novel-coronavirus-2019/situation-reports/. Accessed: 1 April 2020.

16 Countries in the world by population (2020). 2020. Available: https://www.worldometers.info/world-population/population-by-country/. Accessed: 1 April 2020.

17 Lauer SA, Grantz KH, Bi Q, Jones FK, Zheng Q, Meredith HR, et al. The Incubation Period of Coronavirus Disease 2019 (COVID-19) From Publicly Reported Confirmed Cases: Estimation and Application. Ann Intern Med. 2020;172:57782. Medline:32150748 doi:10.7326/M20-0504

18 Huang C, Wang Y, Li X, Ren L, Zhao J, Hu Y, et al. Clinical features of patients infected with 2019 novel coronavirus in Wuhan, China. Lancet. 2020;395:497-506. Medline:31986264 doi:10.1016/S0140-6736(20)30183-5

19 Zhao D, Yao F, Wang L, Zheng L, Gao Y, Ye J, et al. A comparative study on the clinical features of COVID-19 pneumonia to other pneumonias. Clin Infect Dis. 2020:ciaa247. Medline:32161968 doi:10.1093/cid/ciaa247

20 Young BE, Ong SWX, Kalimuddin S, Low JG, Tan SY, Loh J, et al. Epidemiologic Features and Clinical Course of Patients Infected With SARS-CoV-2 in Singapore. JAMA. 2020;323:1488-94. Medline:32125362 doi:10.1001/jama.2020.3204

21 Chang D, Lin M, Wei L, Xie L, Zhu G, Dela Cruz CS, et al. Epidemiologic and Clinical Characteristics of Novel Coronavirus Infections Involving 13 Patients Outside Wuhan, China. JAMA. 2020;323:1092-3. Medline:32031568 doi:10.1001/ jama.2020.1623

22 Wang D, Hu B, Hu C, Zhu F, Liu X, Zhang J, et al. Clinical Characteristics of 138 Hospitalized Patients With 2019 Novel Coronavirus-Infected Pneumonia in Wuhan, China. JAMA. 2020;323:1061-9. Medline:32031570 doi:10.1001/ jama.2020.1585

$23 \mathrm{Ng}$ Y, Li Z, Chua YX, Chaw WL, Zhao A, Er B, et al. Evaluation of the Effectiveness of Surveillance and Containment Measures for the First 100 Patients with COVID-19 in Singapore — January 2-February 29, 2020. MMWR Morb Mortal Wkly Rep. 2020;69:307-11. Medline:32191691 doi:10.15585/mmwr.mm691lel

24 Spiteri G, Fielding J, Diercke M, Campese C, Enouf V, Gaymard A, et al. First cases of coronavirus disease 2019 (COVID-19) in the WHO European Region, 24 January to 21 February 2020. Euro Surv. 2020;25:2000178.

25 COVID-19, Australia: Epidemiology Report 6 (Reporting week ending 19:00 AEDT 7 March 2020). Commun Dis Intell. 2018;2020:44.

26 Xu X-W, Wu X-X, Jiang X-G, Xu K-J, Ying L-J, Ma C-L, et al. Clinical findings in a group of patients infected with the 2019 novel coronavirus (SARS-Cov-2) outside of Wuhan, China: retrospective case series. BMJ. 2020;368:m606. Medline:32075786 doi:10.1136/bmj.m606

27 Bajema KL, Oster A, McGovern O, Lindstrom S, Stenger M, Anderson T, et al. Persons Evaluated for 2019 Novel Coronavirus — United States, January 2020. MMWR Morb Mortal Wkly Rep. 2020;69:166-70. Medline:32053579 doi:10.15585/mmwr.mm6906e1

28 Ki M. Epidemiologic characteristics of early cases with 2019 novel coronavirus (2019-nCoV) disease in Korea. Epidemiol Health. 2020;42:e2020007. Medline:32035431 doi:10.4178/epih.e2020007

29 Chen N, Zhou M, Dong X, Qu J, Gong F, Han Y, et al. Epidemiological and clinical characteristics of 99 cases of 2019 novel coronavirus pneumonia in Wuhan, China: a descriptive study. Lancet. 2020;395:507-13. Medline:32007143 doi:10.1016/S0140-6736(20)30211-7

30 Zhang JJ, Dong X, Cao YY, Yuan YD, Yang YB, Yan YQ, et al. Clinical characteristics of 140 patients infected with SARSCoV-2 in Wuhan, China. Allergy. 2020;75:1730-41. Medline:32077115 doi:10.1111/all.14238

31 Yang X, Yu Y, Xu J, Shu H, Xia J, Liu H, et al. Clinical course and outcomes of critically ill patients with SARS-CoV-2 pneumonia in Wuhan, China: a single-centered, retrospective, observational study. Lancet Respir Med. 2020;8:475-81. Medline:32105632 doi:10.1016/S2213-2600(20)30079-5

32 Wang Z, Yang B, Li Q, Wen L, Zhang R. Clinical Features of 69 Cases with Coronavirus Disease 2019 in Wuhan, China. Clin Infect Dis. 2020:769. Medline:32176772 doi:10.1093/cid/ciaa272

33 Mo P, Xing Y, Xiao Y, Deng L, Zhao Q, Wang H, et al. Clinical characteristics of refractory COVID-19 pneumonia in Wuhan, China. Clin Infect Dis. 2020:ciaa270. Medline:32173725 doi:10.1093/cid/ciaa270

34 Arentz M, Yim E, Klaff L, Lokhandwala S, Riedo FX, Chong M, et al. Characteristics and Outcomes of 21 Critically Ill Patients With COVID-19 in Washington State. JAMA. 2020;323:1612-4. Medline:32191259 doi:10.1001/jama.2020.4326

35 Wu C, Chen X, Cai Y, Xia J, Zhou X, Xu S, et al. Risk Factors Associated With Acute Respiratory Distress Syndrome and Death in Patients With Coronavirus Disease 2019 Pneumonia in Wuhan, China. JAMA Intern Med. 2020;180:1-11. Medline:32167524 doi:10.1001/jamainternmed.2020.0994

36 Zhou F, Yu T, Du R, Fan G, Liu Y, Liu Z, et al. Clinical course and risk factors for mortality of adult inpatients with COVID-19 in Wuhan, China: a retrospective cohort study. Lancet. 2020;395:1054-62. Medline:32171076 doi:10.1016/ S0140-6736(20)30566-3 
37 Statement from the Press Secretary Regarding the President's Coronavirus Task Force. 2020. Available: https://www. whitehouse.gov/briefings-statements/statement-press-secretary-regarding-presidents-coronavirus-task-force/. Accessed: 1 April 2020.

38 AUBREY A. Trump Declares Coronavirus A Public Health Emergency And Restricts Travel From China. 2020. Available: https://www.npr.org/sections/health-shots/2020/01/31/801686524/trump-declares-coronavirus-a-public-health-emergency-and-restricts-travel-from-c. Accessed: 1 April 2020.

39 Trump signs emergency coronavirus package, injecting $\$ 8.3$ billion into efforts to fight the outbreak. 2020. Available: https://markets.businessinsider.com/news/stocks/trump-signs-billion-emergency-funding-package-fight-coronavirus-legislation-covid19-020-3-1028972206. Accessed: 1 April 2020.

40 Testing in the U.S. 2020. Available: https://www.cdc.gov/coronavirus/2019-ncov/cases-updates/testing-in-us.html?CDC_AA_refVal=https\%3A\%2F\%2Fwww.cdc.gov\%2Fcoronavirus\%2F2019-ncov\%2Ftesting-in-us.html. Accessed: 1 April 2020.

41 WAMSLEY L. Trump Administration Announces Measures To Speed Coronavirus Testing. 2020. Available: https://www. npr.org/sections/health-shots/2020/03/13/815363944/trump-administration-announces-measures-to-speed-coronavirus-testing. Accessed: 1 April 2020.

42 Alvarez P. Here's what Trump's coronavirus emergency declaration does. 2020. Available: https://docs.google.com/document/d/1Ug6Wlnys3UdZiFVuNrt0IWbsnwNgJIry8iVuHH5o7xo/edit?ts=5e8e9c61\#. Accessed: 1 April 2020.

43 Booker C. New York launches drive-thru testing site for COVID-19. 2020. Available: https://www.cnn.com/2020/03/13/ politics/states-coronavirus-fema/index.html. Accessed: 1 April 2020.

44 Coronavirus Guidelines for America. 2020. Available: https://www.whitehouse.gov/briefings-statements/coronavirus-guidelines-america/. Accessed: 1 April 2020.

45 Mervosh. S, Lu. D, Swales. V. See Which States and Cities Have Told Residents to Stay at Home. 2020. Available: https:// www.nytimes.com/interactive/2020/us/coronavirus-stay-at-home-order.html. Accessed: 1 April 2020.

46 Sheet F. DHS Notice of Arrival Restrictions on China, Iran and Certain Countries of Europe. 2020. Available: https:// www.dhs.gov/news/2020/03/17/fact-sheet-dhs-notice-arrival-restrictions-china-iran-and-certain-countries-europe. Accessed: 1 April 2020.

47 Map: Coronavirus and School Closures. 2020. Available: https://www.edweek.org/ew/section/multimedia/map-coronavirus-and-school-closures.html. Accessed: 1 April 2020.

48 Winck B. House passes $\$ 2$ trillion coronavirus stimulus bill, which includes direct payments to Americans and business loans. 2020. Available: https://www.businessinsider.com/house-passes-coronavirus-stimulus-bill-payments-business-loans-hospital-aid-2020-3. Accessed: 1 April 2020.

49 Notice of the People 's Government of Hubei Province on Strengthening the Prevention and Control of Pneumonia Infected by New Coronavirus. 2020. Available: https://archive.vn/20200205092902/http://www.hubei.gov.cn/xxgk/ gsgg/202001/t20200122_2013895.shtml. Accessed: 1 April 2020.

50 China coronavirus: Lockdown measures rise across Hubei province. 2020. Available: https://www.bbc.com/news/worldasia-china-51217455. Accessed: 1 April 2020.

51 Zhejiang: 17 newly diagnosed cases of new coronavirus infection and pneumonia were launched, and the first-level response to major public health emergencies was initiated. Available: http://www.xinhuanet.com/2020-01/23/c_1125497886.htm. Accessed: 1 April 2020.

52 All 31 provinces in Mainland China have initiated first-level response to public health emergencies. Available: http:// china.caixin.com/2020-01-29/101509411.html. Accessed: 1 April 2020.

53 Xiangyang Railway Station is closed, and the last prefecture-level city "Hubei" in Hubei Province. 2020. Available: https:// www.thepaper.cn/newsDetail_forward_5671283. Accessed: 1 April 2020.

54 After Wenzhou, Hangzhou, Taizhou and Ningbo have implemented the most restrictive order. 2020. Available: https:// cbgc.scol.com.cn/news/227255. Accessed: 1 April 2020

55 South Korea learned its successful Covid-19 strategy from a previous coronavirus outbreak: MERS. 2020. Available: https://thebulletin.org/2020/03/south-korea-learned-its-successful-covid-19-strategy-from-a-previous-coronavirus-outbreak-mers/. Accessed: 1 April 2020.

56 Korea Bars Foreigners Traveling From Hubei Province S. 2020. Available: http://tbs.seoul.kr/eFm/newsView.do?typ_800=N\&idx_800=2383586\&seq_800=. Accessed: 1 April 2020.

57 Ministry of Education Opening on March 9. 2020. Available: http://www.donga.com/news/article/all/20200223/99835113/2. Accessed: 1 April 2020.

58 South Korea pioneers coronavirus drive-through testing station. 2020. Available: https://edition.cnn.com/2020/03/02/ asia/coronavirus-drive-through-south-korea-hnk-intl/index.html. Accessed: 1 April 2020.

59 Italy suspends all China flights as coronavirus cases confirmed in Rome. 2020. Available: https://www.thelocal. it/20200131/italy-suspends-all-china-flights-after-coronavirus-cases-confirmed-in-rome/. Accessed: 1 April 2020.

60 Coronavirus, in ten Lombard municipalities: 50 thousand people forced to stay at home. Quarantine at the Milanese hospital in Baggio. 2020. Available: https://docs.google.com/document/d/1Ug6W1nys3UdZiFVuNrtOIWbsnwNgJIry8iVuHH5o7xo/edit?ts=5e8e9c61\#. Accessed: 1 April 2020.

61 Italy orders closure of all schools and universities due to coronavirus. 2020. Available: https://www.theguardian.com/ world/2020/mar/04/italy-orders-closure-of-schools-and-universities-due-to-coronavirus. Accessed: 1 April 2020.

62 Coronavirus: Italy extends emergency measures nationwide. 2020. Available: https://www.bbc.com/news/world-europe-51810673. Accessed: 1 April 2020. 
63 Italy ramps up coronavirus lockdown, Merkel warns virus could infect two-thirds of Germany. 2020. Available: https:// www.washingtonpost.com/world/europe/merkel-coronavirus-germany/2020/03/11/e276252a-6399-11ea-8a8e5c5336b32760_story.html. Accessed: 1 April 2020.

64 Coronavirus emergency, the government's plan rises to 25 billion. Gualtieri to the EU: 'Stimulus is needed'. 2020. Available: https://www.repubblica.it/economia/2020/03/11/news/emergenza_coronavirus_conferenza_stampa_conte_misure_ economiche-250924846/. Accessed: 1 April 2020.

65 Alessandria, buffer in the car as in the drive in: "We will make 300 a day". 2020. Available: https://torino.repubblica.it/cronaca/2020/04/01/news/alessandria_tampone_in_auto_come_al_drive_in_ne_faremo_300_al_giorno_252867384/?ref=RHPPLF-BH-I252756236-C8-P8-S5.2-T1. Accessed 1 April 2020.

66 Iranian Doctors Call For. 'Long Holiday' To Contain Coronavirus, As Sixth Victim Dies. 2020. Available: https://en.radiofarda.com/a/iranian-doctors-call-for-long-holiday-to-contain-coronavirus-outbreak/30449047.html. Accessed: 1 April 2020.

67 Universities IACO, Schools ACDTR. 2020. Available: https://en.radiofarda.com/a/iran-announces-closure-of-universities-schools-to-fight-coronavirus/30449711.html. Accessed: 1 April 2020.

68 Coronavirus: Iran limits travel and urges banknote avoidance. 2020. Available: https://www.thelocal.it/20200131/italy-suspends-all-china-flights-after-coronavirus-cases-confirmed-in-rome/. Accessed: 1 April 2020.

69 Shiite Hardliners in Iran Storm 2 Shrines That Were Closed to Stop Coronavirus Spread. 2020. Available: https://time. com/5804546/iran-shiite-storm-coronavirus/. Accessed 9 April 2020.

70 Germany enacts new health security measures against coronavirus infections. 2020. Available: https://www.reuters.com/ article/us-china-health-germany-idUSKCN20M34J. Accessed: 1 April 2020.

71 Disaster event: These rules apply in Bavaria. 2020. Available: https://www.br.de/nachrichten/bayern/katastrophenfall-in-bayern-diese-regeln-gelten-ab-sofort,RtNxMZq. Accessed: 2 April 2020.

72 Germany halts flights from Iran and China over coronavirus: Bild. 2020. Available: https://www.reuters.com/article/ us-health-coronavirus-germany-flights-bi/germany-halts-flights-from-iran-and-china-over-coronavirus-bild-idUSKBN2131XA. Accessed: 1 April 2020.

73 Deutschland im Shutdown-Modus - Die Alternativlos-Kanzlerin kehrt zurück. 2020. Available: https://www.handelsblatt.com/politik/deutschland/coronakrise-deutschland-im-shutdown-modus-die-alternativlos-kanzlerin-kehrt-zurueck/25650658.html?ticket=ST-2398387-tNfURd6JZfAIhM9SdoBt-ap5. Accessed: 1 April 2020.

74 Einreiseverbot in EU-Staaten - jede verfügbare Hilfe für die Wirtschaft. 2020. Available: https://www.welt.de/politik/ deutschland/article206623191/Coronavirus-Einreiseverbot-in-EU-Staaten-jede-verfuegbare-Hilfe-fuer-die-Wirtschaft. html. Accessed 1 April 2020.

75 Gericht kippt Reiseverbot für Einwohner Mecklenburg-Vorpommerns. 2020. Available: https://www.sueddeutsche.de/ panorama/coronavirus-news-deutschland-1.4828033. Accessed: 1 April 2020.

76 Bayern impose curfew! 2020. Available: https://www.nordkurier.de/politik-und-wirtschaft/bayern-verhaengt-ausgangssperre-2038792303.html. Accessed: 2 April 2020.

77 Contact bans on more than two people, hairdressers too - the federal and state governments have agreed on this. 2020. Available: https://www.welt.de/politik/deutschland/article206725829/Coronavirus-Deutschland-Kontaktverbote-zu-mehr-als-zwei-Personen-Friseure-zu.html. Accessed: 1 April 2020.

78 Spain prohibits all direct flights from Italy until March 25. 2020. Available: https://docs.google.com/document/d/1Ug6Wlnys3UdZiFVuNrtOIWbsnwNgJIry8iVuHH5o7xo/edit?ts=5e8e9c61\#. Accessed: 1 April 2020.

79 The Community of Madrid decrees the mandatory closure of bars, restaurants and clubs until March 26. 2020. Available: https://www.elindependiente.com/vida-sana/salud/2020/03/13/la-comunidad-de-madrid-decreta-el-cierre-obligatorio-de-bares-restaurantes-y-tiendas/. Accessed: 1 April 2020.

80 Spain to impose nationwide lockdown - El Mundo. 2020. Available: https://nationalpost.com/pmn/health-pmn/spainto-impose-nationwide-lockdown-el-mundo. Accessed: 1 April 2020.

81 Coronavirus, last minute in Spain: Marlaska suspends free movement and reestablishes border controls. 2020. Available: https://www.elmundo.es/ciencia-y-salud/salud/2020/03/16/5e6flb62fdddff6d798b4618.html. Accessed: 2 April 2020.

82 Predictions and role of interventions for COVID-19 outbreak in India. 2020. Available: https://medium.com/@covind_19/ predictions-and-role-of-interventions-for-covid-19-outbreak-in-india-52903e2544e6. Accessed: 1 April 2020.

83 Coronavirus: All international arrivals to India to share travel history at airports. 2020. Available: https://economictimes.indiatimes.com/news/politics-and-nation/all-international-arrivals-to-give-travel-history-at-airports/articleshow/74467810. cms?from=mdr. Accessed: 2 April 2020.

84 ICMR to test for community transmission of Covid-19. 2020. Available: https://indianexpress.com/article/india/icmr-totest-for-community-transmission-of-covid-19-6313521/. Accessed: 2 April 2020.

85 Coronavirus: ICMR recommends hydroxychloroquine for high-risk population. 2020. Available: https://economictimes. indiatimes.com/industry/healthcare/biotech/pharmaceuticals/indias-covid-task-force-recommends-hydroxychloroquinefor-high-risk-patients-with-strict-riders/articleshow/74774540.cms?from=mdr. Accessed 2 April 2020.

86 Coronavirus: India enters 'total lockdown' after spike in cases. 2020. Available: https://www.bbc.com/news/world-asiaindia-52024239. Accessed: 2 April 2020.

8764 global airlines have completely stopped flying scheduled flights due to travel bans, airspace closures, and low demand for travel. 2020. Available: https://www.businessinsider.com/coronavirus-global-airlines-stopping-flights-suspending-operations-2020-3. Accessed 2 April 2020. 
88 FM Nirmala Sitharaman announces Rs 1.7 lakh crore relief package for poor. 2020. Available: https://economictimes. indiatimes.com/news/economy/policy/fm-nirmala-sitharaman-announces-rs-1-7-lakh-crore-relief-package-for-poor/ articleshow/74825054.cms?from=mdr. Accessed: 2 April 2020.

89 SARS-COV-2 TEST TRACKER. 2020. Available: https://www.finddx.org/covid-19/covid-19-backuplp/test-tracker/. Accessed: 2 April 2020.

90 To understand the global pandemic, we need global testing - the Our World in Data COVID-19 Testing dataset. 2020. Available: https://ourworldindata.org/covid-testing. Accessed: 2 April 2020.

91 Li Q, Guan X, Wu P, Wang X, Zhou L, Tong Y, et al. Early Transmission Dynamics in Wuhan, China, of Novel Coronavirus-Infected Pneumonia. N Engl J Med. 2020;382:1199-207. Medline:31995857 doi:10.1056/NEJMoa2001316

92 Zhao D, Yao F, Wang L, Zheng L, Gao Y, Ye J, et al. A comparative study on the clinical features of COVID-19 pneumonia to other pneumonias. Clin Infect Dis. 2020:756. Medline:32161968 doi:10.1093/cid/ciaa247

93 Wang M, Cao R, Zhang L, Yang X, Liu J, Xu M, et al. Remdesivir and chloroquine effectively inhibit the recently emerged novel coronavirus (2019-nCoV) in vitro. Cell Res. 2020;30:269-71. Medline:32020029 doi:10.1038/s41422020-0282-0

94 Gao J, Tian Z, Yang X. Breakthrough: Chloroquine phosphate has shown apparent efficacy in treatment of COVID-19 associated pneumonia in clinical studies. Biosci Trends. 2020;14:72-3. Medline:32074550 doi:10.5582/bst.2020.01047

95 Gautret P, Lagier J-C, Parola P, Hoang VT, Meddeb L, Mailhe M, et al. Hydroxychloroquine and azithromycin as a treatment of COVID-19: results of an open-label non-randomized clinical trial. Int J Antimicrob Agents. 2020;56:105949. Medline:32205204 doi:10.1016/j.ijantimicag.2020.105949

96 Shen C, Wang Z, Zhao F, Yang Y, Li J, Yuan J, et al. Treatment of 5 Critically Ill Patients With COVID-19 With Convalescent Plasma. JAMA. 2020;323:1582-9. Medline:32219428 doi:10.1001/jama.2020.4783

97 Severe Outcomes Among Patients with Coronavirus Disease. 2019 (COVID-19) — United States, February 12-March 16, 2020. MMWR Morb Mortal Wkly Rep. 2020;69:343-6. Medline:32214079 doi:10.15585/mmwr.mm6912e2

98 Forecasting COVID-19 impact on hospital bed-days, ICU-days, ventilator days and deaths by US state in the next 4 months. Available: http://www.healthdata.org/research-article/forecasting-covid-19-impact-hospital-bed-days-icu-daysventilator-days-and-deaths. Accessed: 2 April 2020.

99 Onder G, Rezza G, Brusaferro S. Case-Fatality Rate and Characteristics of Patients Dying in Relation to COVID-19 in Italy. JAMA. 2020. Online ahead of print. Medline:32203977 doi:10.1001/jama.2020.4683

100 Italian doctors on coronavirus frontline face tough calls on whom to save. 2020. Available: https://www.politico.eu/article/coronavirus-italy-doctors-tough-calls-survival/. Accessed: 1 April 2020.

101 Rajgor DD, Lee MH, Archuleta S, Bagdasarian N, Quek SC. The many estimates of the COVID-19 case fatality rate. Lancet Infect Dis. 2020;20:776-7. Medline:32224313 doi:10.1016/S1473-3099(20)30244-9

102 Furukawa NW, Brooks JT, Sobel J. Evidence Supporting Transmission of Severe Acute Respiratory Syndrome Coronavirus 2 While Presymptomatic or Asymptomatic. Emerg Infect Dis. 2020;26:e201595. Medline:32364890 doi:10.3201/ eid2607.201595

$103 \mathrm{Xu}$ X, Sun J, Nie S, Li H, Kong Y, Liang M, et al. Seroprevalence of immunoglobulin M and G antibodies against SARSCoV-2 in China. Nat Med. 2020. Online ahead of print. Medline:32504052 doi:10.1038/s41591-020-0949-6

104 World Health O. Population-based age-stratified seroepidemiological investigation protocol for coronavirus 2019 (COVID-19) infection, 26 May 2020. Geneva: World Health Organization, 2020 2020. Report No.: Contract No.: WHO/2019-nCoV/Seroepidemiology/2020.2. 